\title{
PENGARUH PENERAPAN PRINSIP GOOD CORPORATE GOVERNANCE TERHADAP KINERJA NON-KEUANGAN PADA PERUSAHAAN B'RIGHT PLN BATAM
}

\author{
Sajidah Decha Puspa ${ }^{1)}$ \\ Yulinda $^{2)}$ \\ Program Studi Akuntansi Manajerial, Politeknik Negeri Batam \\ Jl. Ahmad Yani, Batam Centre, Batam 29461, Indonesia \\ ${ }^{1)}$ E-mail: sajidahdechap@gmail.com ${ }^{1)}$ \\ ${ }^{2)}$ E-mail: yulinda@polibatam.ac.id ${ }^{2)}$
}

\begin{abstract}
This study aims to determine the effect of the application of GCG principles on non-financial performance. Non-financial performance as the dependent variable and the independent variables in this study are transparency, accountability, responsibility, independency and fairness. The focus of this research is to find out the extent of the effect of GCG implementation on non-financial performance at the company B'right PLN Batam. The method used is non-probability sampling with purposive sampling method and obtained through questionnaires with the number of respondents as many as 40. Based on the results of the t test shows the transparency hypothesis has a positive and significant effect on non-financial performance, the accountability hypothesis has no significant effect on non-financial performance, the responsibility hypothesis has no significant effect on non-financial performance, the independency hypothesis has a significant effect on non-financial performance and the fairness hypothesis has a significant effect on non-financial performance. Based on the results of $R 2$ testing the application of the GCG principle has an effect of $84.6 \%$ on the dependent variable in this study, then the principles of GCG have a significant effect on non-financial performance.
\end{abstract}

Keywords: Non-financial performance, transparency, accountability, independence, fairness

\begin{abstract}
Abstrak
Penelitian ini bertujuan untuk mengetahui pengaruh penerapan prinsip GCG terhadap kinerja non-keuangan. Kinerja non-keuangan sebagai variabel dependen dan variabel independen dalam penelitian ini adalah transparency, accountability, responsibility, independency dan fairness. Fokus penilitian ini adalah untuk mengetahui sejauh manakah pengaruh penerapan GCG terhadap kinerja non-keuangan pada perusahaan b'right PLN Batam. Metode yang digunakan yaitu non-probability sampling dengan metode purposive sampling dan didapatkan melalui kuisioner dengan jumlah responden sebanyak 40. Berdasarkan hasil uji t menunjukkan hipotesis transparency berpengaruh positif dan signifikan terhadap kinerja non-keuangan, hipotesis accountability berpengaruh tidak
\end{abstract}


signifikan terhadap kinerja non-keuangan, hipotesis responsibility berpengaruh tidak signifikan terhadap kinerja non-keuangan, hipotesis independency berpengaruh signifikan terhadap kinerja non-keuangan dan hipotesi fairness berpengaruh signifikan terhadap kinerja non-keuangan. Berdasarkan hasil uji $\mathrm{R}^{2}$ penerapan prinsip GCG berpengaruh sebesar $84,6 \%$ terhadap variabel dependen dalam penelitian ini, maka secara simultan prinsip GCG berpengaruh signifikan terhadap kinerja non-keuangan.

Kata Kunci: Kinerja Non-keuangan, transparency, accountability, independence, fairness 


\section{Pendahuluan}

Kehidupan ekonomi kita mengenal istilah perusahaan dan badan usaha, kedua istilah tersebut berbeda tetapi diberi pengertian sama. Artinya sebagai suatu organisasi yang didalamnya diselenggarakan kerjasama antara faktor produksi untuk menghasilkan barang atau jasa untuk melayani kepentingan umum sekaligus kelangsungan usaha. Pemilihan bentuk perusahaan merupakan masalah yang timbul pada saat perusahan didirikan. Pemilihan bentuk perusahaan perlu pertimbangan yang matang untuk mencegah terjadinya hal-hal yang tidak diinginkan, dengan bentuk yang jelas menurut hukum dapat diharapkan bahwa perusahaan akan dapat dengan tegas menentukan langkah-langkah yang harus dilakukan untuk mencapai tujuan. Pemerintah Indonesia mendirikan Perusahaan BUMN dan BUMD dengan dua tujuan utama, yaitu tujuan yang bersifat ekonomi dan tujuan yang bersifat sosial. Dalam tujuan yang bersifat ekonomi, Perusahaan BUMN dan BUMD dimaksudkan untuk mengelola sektor-sektor bisnis strategis agar tidak dikuasai pihak-pihak tertentu.

Salah satu tujuan utama dalam pendirian sebuah perusahaan adalah untuk meningkatkan kesejahteraan pemiliknya atau pemegang saham, atau dengan memaksimalkan kekayaan pemegang saham melalui peningkatan kinerja. Peningkatan kinerja dan dapat dicapai jika perusahaan mampu beroperasi dengan mencapai laba yang ditargetkan. Pemerintah sadar bahwa tidak hanya perusahaan swasta saja yang menerapkan Good Corporate Governance (GCG) maka dari itu Perusahaan BUMN yang mempunyai peran penting terhadap perekonomian nasional juga bisa memperbaiki citra dengan mengedepankan tata kelola perusahaan yang baik dan transparan.

Secara umum, tata kelola perusahaan merupakan suatu struktur yang diterapkan agar perusahaan dapat semakin berkembang dan terus meningkatkan kinerja dengan didasari oleh perundang-undangan dan nilai-nilai etika. Salah satu cara untuk meningkatkan kinerja perusahaan tersebut adalah dengan menerapkan Good Corporate Governance (GCG). Sebagaimana yang dijelaskan dalam Forum Of Corporate Governance Indonesia (2016) bahwa definisi Good Corporate Governance (GCG) menurut Cadbury Committee Of United Kingdom adalah mengarahkan dan mengendalikan perusahaan agar tercapai keseimbangan antara kekuatan dan kewenangan perusahaan.

Penerapan Corporate Governance

berdasarkan Keputusan Menteri Negara Badan Usaha Milik Negara Nomor: Kep-117/M-MBU/2002 diartikan sebagai suatu proses dan struktur yang digunakan oleh Organ Perusahaan (Rapat Umum Pemegang Saham, Dewan Komisaris dan Direksi) yang dilakukan untuk meningkatan kinerja perusahaan melalui supervisi atau monitoring kinerja manajemen dan menjamin akuntabilitas manajemen terhadap stakeholder dengan mendasarkan pada kerangka peraturan. Jika mekanisme Corporate Governance tidak diterapkan atau tidak berfungsi dengan baik dalam perusahaan, maka hal tersebut dapat menurunkan kepercayaan investor dan nilai perusahaan, serta dapat menyebabkan kinerja perusahaan yang kurang baik.

Salah satu Perusahaan Sektor Kelistrikan adalah B'right PLN Batam merupakan anak perusahaan PT PLN (Persero), sebagai unit mandiri yang mengelola kelistrikan dari hulu sampai hilir. Mengingat lingkungan bisnis bersifat dinamis, maka sebagai upaya mencapai standar kerja yang baik bagi perusahaan. Untuk mendukung kinerja b'right PLN Batam salah satu langkah yang ditempuh oleh b'right PLN Batam untuk meningkatkan kinerja perusahaan adalah menerapkan prinsip dan praktik good corporate governance (GCG) baik dalam manajemen maupun pengelolaan bisnis usahanya. Prinsip-prinsip GCG yang diterapkan oleh meliputi transparency, accountability, responsibility, fairness dan independency.

\section{Kerangka Teori}

\subsection{Teori dan Penelitian Terdahulu}

Pengertian Good Corporate Governance dalam Peraturan Menteri Negara Badan Usaha Milik Negara Nomor PER-01/MBU/2011 tentang Penerapan Tata Kelola yang baik pada Badan Usaha Milik Negara 
adalah prinsip-prinsip yang mendasari suatu proses dan mekanisme pengelolaan perusahaan yang berlandaskan pada peraturan perundang-undangan dan etika dalam berusaha. Dalam rangka penerapan GCG, BUMN wajib melakukan secara konsisten dan berkelanjutan dengan berpedoman pada Peraturan Menteri dengan memperhatikan ketentuan dan norma yang berlaku serta anggaran dasar BUMN.

Penerapan praktik GCG dapat diartikan sebagai suatu proses dan struktur yang digunakan Organ Perusahaan untuk meningkatkan keberhasilan usaha dan akuntabilitas perusahaan guna mewujudkan nilai pemegang saham dengan tetap memperhatikan kepentingan stakeholders yang berlandaskan pada peraturan perundang-undangan dan nilai etika. Ruang lingkup dalam kebijakan GCG meliputi segenap jajaran perusahaan diantaranya pemegang saham, direksi serta pegawai yang telah ditunjuk dan ditugaskan untuk melaksanakan kegiatan pembinaan, pengawasan dan pengelolaan perusahaan dalam menjalankan aktivitas bisnis perusahaan yang sejalan dengan prinsip GCG (PLNBatam, 2018).

Penelitian tentang pengaruh penerapan prisnsip good corporate governance terhadap kinerja non-keuangan menunjukkan bahwa penerapan prinsip good corporate governance berpengaruh terhadap kinerja. Berikut hasil - hasil penelitian penerapan prinsip good corporate governance terhadap kinerja.

Sebagian besar hasil penelitian hipotesis di atas terdukung oleh penelitian Ramli \& Ramli (2015) yang menunjukkan bahwa ada terjadi peningkatan profitabilitas bagi perusahan yang menerapkan Good corporate governance di Malaysia, dan hal tersebut makin meningkatkan kesadaran perusahaan dalam menerapkan good corporate governance dan penelitian dari Peter \& David (2014) yang menemukan bahwa penerapan praktik good corporate governance akan membantu dalam memberikan kontribusi kinerja organisasi yang efektif.

Untuk hasil penelitian hipotesis $\mathrm{H}_{2}$ dan $\mathrm{H}_{3}$ terdukung oleh hasil penelitian dari Aggarwal (2013) yang menyatakan good corporate governance memang memberikan dampak positif bagi perusahaan namun tidak signifikan bagi profitabilitas perusahaan yang listing S\&P CNX Nifty 50 Index di India, hal yang sama juga ditemukan oleh Velnampy (2013) dimana faktor penentu dari good corporate governance ternyata tidak berpengaruh terhadap kinerja perusahaan.

\subsection{Hipotesis Penelitian}

$\mathrm{H}^{1}$ : Penerapan prinsip Good Corporate Governance Transparancy berpengaruh terhadap kinerja non-keuangan pada perusahaan b'right PLN Batam.

$\mathrm{H}^{2}$ : Penerapan prinsip Good Corporate Governance Accountability berpengaruh terhadap kinerja non-keuangan pada perusahaan b'right PLN Batam.

$\mathrm{H}^{3}$ : Penerapan prinsip Good Corporate Governance Responsibility berpengaruh terhadap kinerja non-keuangan pada perusahaan b'right PLN Batam.

$\mathrm{H}^{4}$ : Penerapan prinsip Good Corporate Governance Independency berpengaruh terhadap kinerja non-keuangan pada perusahaan b'right PLN Batam.

$\mathrm{H}^{5}$ : Penerapan prinsip Good Corporate Governance Fairness berpengaruh terhadap kinerja non-keuangan pada perusahaan b'right PLN Batam.

$\mathrm{H}^{6}$ : Penerapan prinsip Good Corporate Governance berpengaruh secara simultan terhadap kinerja non-keuangan pada perusahaan b'right PLN Batam

\section{Metode Penelitian}

\subsection{Populasi dan Sampel}

Jenis data yang digunakan oleh peneliti dalam penelitian ini adalah data primer yang diperoleh langsung dari subjek penelitian dengan menggunakan alat pengukuran atau alat pengambilan data langsung pada subjek sebagai sumber informasi yang dicari.

Sumber data yang diambil untuk mendapatkan informasi mengenai penelitian adalah perusahaan b'riht PLN Batam berupa kuisioner.

Penelitian ini menggunakan instrument penelitian berupa kuisioner dengan skala likert yaitu skala yang digunakan untuk mengukur sikap, pendapat dan persepsi seorang atau sekelompok orang tentang 
fenomena sosial. Dalam penelitian ini, fenomena sosial telah ditetapkan secara spesifik oleh peneliti, yang selanjutnya disebutkan sebagai variabel penelitian. Dengan skala likert, maka variabel yang diukur dijabarkan menjadi indikator variabel. Kemudian indikator tersebut dijadikan sebagai titik tolak ukur untuk menyusun item-item instrumen yang dapat berupa pertanyaan atau pernyataan.

Populasi yang digunakan dalam penelitian ini adalah seluruh jajaran struktural di Perusahaan b'right PLN Batam mulai dari Manajer hingga DIrektur Utama. Peneliti akan menyebarkan data sebanyak 40 kuisioner yang diberikan pada 40 karyawan yang berada pada jajaran stuktural di perusahaan b'right PLN Batam mulai Manajer hingga Direktur Utama sebagai sampel penelitian.

Pengambilan atau penarikan sampel dalam penelitian ini menggunakan teknik non-probability sampling dengan metode purposive sampling. Purposive sampling adalah teknik penentuan sampel berdasarkan suatu kinerja tertentu. Kriteria yang digunakan untuk menentukan sampel adalah karyawan b'right PLN Batam dan memiliki posisi minimal Manajer. Peneliti memilih kriteria tersebut karena di perusahaan b'right PLN Batam jajaran struktural mulai dari Manajer hingga Direktur Utama merupakan penganggungjawab atas keberlangsungan penerapan GCG.

\subsection{Metode Analisis Data}

Teknik pengumpulan data yang digunakan dalam penelitian ini adalah penyebaran kuisioner (angket) yang dilakukan dengan cara memberi seperangkat pertanyaan kepada responden agar peneliti memperoleh data secara langsung. Tujuan penyebaran kuesioner (angket) adalah mencari informasi yang lengkap mengenai suatu masalah dari responden tanpa merasa khawatir bila responden memberikan jawaban yang tidak sesuai dengan kenyataan dalam pengisian daftar pertanyaan atau pernyataan.

Dengan demikian, penelitian akan memperoleh data atau fakta yang bersifat teoritis yang memiliki hubungan dengan permasalahan yang akan dibahas. Jumlah pertanyaaan pada kuesioner ini sebanyak 34 butir soal dengan bentuk alternative pilihan jawaban.

Data dalam penelitian ini diolah melalui proses tabulating pada Microsoft Excel 2007 dan kemudian dilakukan analisis statistik dengan menggunakan program SPSS versi 24 (Statistical Product and Service Solution). Signifikansi koefisien pada setiap variabel dalam penelitian ini menggunakan p-value dengan tingkat signifikan alpha sebesar 0,05 atau $5 \%$.

Ghozali (2012) menyatakan bahwa uji validitas digunakan untuk mengukur sah atau valid tidaknya suatu kuesioner. Suatu instrumen yang sah atau valid memiliki nilai validitas yang tinggi dan sebaliknya untuk instrumen yang kurang valid berarti memiliki validitas yang rendah. Teknik pengujian yang sering digunakan para peneliti untuk uji validitas adalah menggunakan korelasi Bivariate Pearson.

Menganalisis dengan cara mengkorelasikan masing-masing skor item dengan skor total. Skor total adalah penjumlahan dari keseluruhan item-item pertanyaan yang berkorelasi signifikan dengan skor total menunjukkan item-item tersebut mampu memberikan dukungan dalam mengungkap apa yang ingin diungkap adalah valid. Dengan jumlah sampel (n) adalah 40 tingkat signifikansi 0,05 maka $\mathrm{r}$ tabel pada penelitian ini adalah : $\mathrm{R}(0,05: 40-3=37) 0,3160$ Bila : $r_{\text {hitung }}>r_{\text {tabel}}$, maka pernyataan tersebut dinyatakan valid.

$\mathrm{r}_{\text {hitung }}<\mathrm{r}_{\text {tabel }}$, maka pernyataan tersebut dinyatakan tidak valid.

Reliabilitas adalah alat untuk mengukur suatu kuesioner yang merupakan indikator dari peubah atau konstruk. Suatu kuesioner dikatakan reliabel atau handal jika jawaban seseorang terhadap pernyataan adalah konsisten atau stabil dari waktu ke waktu. Reliabilitas suatu test merujuk pada derajat stabilitas, konsistensi, daya prediksi, dan akurasi. Pengukuran yang memiliki reliabilitas yang tinggi adalah pengukuran yang dapat menghasilkan data yang reliable (Ghozali, 2012).

Uji Reliabilitas merupakan alat untuk mengukur suatu kuesioner yang merupakan indikator dari variabel atau konstruk. Suatu kuesioner dikatakan reliabel atau handal jika jawaban seseorang terhadap 
pertanyaan konsisten atau stabil dari waktu ke waktu. SPSS memberikan fasilitas untuk mengukur reliabilitas dengan uji statistik Cronbach Alpha $(\alpha)$. Suatu variabel dikatakan reliabel jika memberikan nilai $\alpha>0,60$ (Aripin, 2017).

Menurut Ghozali (2012) uji asumsi klasik adalah pengujian asumsi-asumsi statistik yang harus dipenuhi pada analisis regresi linear berganda. Model regresi dikatakan menghasilkan estimator yang baik apabila memenuhi asumsi-asumsi yang berpengaruh pada pola perubahan variabel dependen yaitu kenormalan data, tidak terjadi autokorelasi, tidak terjadi multikolinearitas, dan tidak terjadi heteroskedastisitas. Sebelum dilakukan analisis regresi linear berganda, terlebih dahulu dilakukan pengujian asumsi klasik sebagai berikut:

Uji normalitas bertujuan untuk mengetahui apakah dalam model regresi, variabel terikat dan variabel bebas memiliki distribusi normal atau tidak, karena model regresi yang baik memiliki distribusi data yang normal. Pembuktian apakah data tersebut memiliki distribusi normal atau tidak, dapat dilihat pada bentuk distribusi datanya, yaitu pada histogram maupun normal probability plot. Pada histogram, data dikatakan memiliki distribusi yang normal jika data tersebut berbentuk seperti lonceng. Sedangkan pada normal probability plot, data dikatakan normal jika ada penyebaran titik-titik disekitar garis diagonal dan penyebarannya mengikuti arah garis diagonal (Aripin, 2017), menyebutkan jika data menyebar di sekitar garis diagonal dan mengikuti arah garis diagonal maka model regresi memenuhi asumsi normalitas.

Uji multikolinieritas bertujuan untuk menguji apakah terdapat korelasi antar variabel independen dalam sebuah model regresi. Model regresi yang baik seharusnya tidak terjadi korelasi di antara variabel independennya. Multikolinieritas dapat dilihat dari nilai tolerance dan variance inflation factor (VIF). Jika nilai tolerance $>0,10$ dan nilai $\mathrm{VIF}<10$, maka model regresi tersebut bebas dari multikolinieritas (Ghozali, 2012).

Analisis regresi linear adalah pengembangan analisis regresi sederhana terhadap aplikasi yang terdiri dari dua atau lebih variabel independen untuk menduga nilai dari variabel dependen (Aripin, 2017). Analisis regresi linear dapat digunakan untuk mengetahui bagaimana pengaruh variabel bebas yaitu: Transparancy (X1), Accountability (X2), Responsibility (X3), Independency (X4) dan Fairness (X5) terhadap Kinerja Non-keuangan (Y) pada perusahaan b'Right PLN Batam. Dalam penelitian ini, digunakan model regresi linear berganda. Rumusnya adalah sebagai berikut:

$\mathrm{Y}=\mathrm{a}+\mathrm{b} 1 \mathrm{X} 1+\mathrm{b} 2 \mathrm{X} 2+\mathrm{b} 3 \mathrm{X} 3+\mathrm{b} 4 \mathrm{X} 4+\mathrm{b} 5 \mathrm{X} 5+\mathrm{e}$

Uji statistik $t$ digunakan untuk mengetahui seberapa jauh masing-masing variabel transparancy, accountability, responsibility, independency, dan fairness dalam menerangkan variabel kinerja perusahaan. Dalam hal ini, apakah masing-masing variabel transparancy, accountability, responsibility, independency, dan fairness mempengaruhi variabel kinerja non-keuangan.

Penelitian ini dilakukan dengan melihat langsung pada hasil perhitungan koefisien regresi melalui SPSS pada bagian Unstandardized Coefficients dengan membandingkan Unstandardized Coefficients B dengan Standard error of estimate sehingga akan didapatkan hasil yang dinamakan thitung (Aripin, 2017). sebagai dasar pengambilan keputusan dapat digunakan kriteria pengujian sebagai berikut:

1. Apabila $t_{\text {hitung }}>t_{\text {tabel }}$ dan tingkat signifikansi $<a$ $(0,05)$, maka $\mathrm{H}_{0}$ ditolak dan $\mathrm{H}_{1}$ diterima. Hal ini berarti variabel independen secara individual berpengaruh terhadap variabel dependen.

2. Apabila $t_{\text {hitung }}<\mathrm{t}_{\text {tabel }}$ dan tingkat signifikansi $>\mathrm{a}$ $(0,05)$, maka $\mathrm{H}_{0}$ diterima dan $\mathrm{H}_{1}$ ditolak. Hal ini berarti variabel independen secara individual tidak berpengaruh terhadap variabel dependen.

Uji F bertujuan untuk menunjukkan apakah semua variabel independen yang dimasukkan ke dalam model secara simultan atau bersama-sama mempunyai pengaruh terhadap variabel dependen (Aripin, 2016). Menentukan $\mathrm{F}_{\text {tabel }}$ dan $\mathrm{F}_{\text {hitung }}$ dengan kepercayaan sebesar $95 \%$ atau taraf signifikan sebesar 5\% $(0,05)$. Dalam penelitian ini menunjukkan apakah variabel independen yang terdiri dari variabel transparancy, accountability, responsibility, independency, dan fairness untuk menjelaskan variabel terikatnya, yaitu 
kinerja non-keuangan. Adapun kriteria pengujian uji F adalah sebagai berikut:

Dengan membandingkan nilai $F_{\text {hitung }}$ dengan $F_{\text {tabel }}$ apabila $\mathrm{F}_{\text {hitung }}>\mathrm{F}_{\text {tabel, }}$ maka $\mathrm{H}_{6}$ diterima. Berarti masing-masing variabel independen secara bersama-sama mempunyai pengaruh yang signifikan terhadap variabel dependen.

Begitu juga sebaliknya, dengan membandingkan nilai $\mathrm{F}_{\text {hitung }}$ dengan $\mathrm{F}_{\text {tabel}}$, apabila $\mathrm{F}_{\text {hitung }}<\mathrm{F}_{\text {tabel}}$, maka $\mathrm{H}_{5}$ ditolak, Berarti masing-masing variabel independen secara bersama-sama tidak mempunyai pengaruh yang signifikan terhadap variabel dependen.

Koefisien determinasi $\left(R^{2}\right)$ pada intinya mengukur seberapa jauh kemampuan model dalam menerangkan variasi variabel dependen. Nilai koefisien determinasi $\left(\mathrm{R}^{2}\right)$ antara nol dan satu. Nilai $\mathrm{R}^{2}$ yang kecil berarti kemampuan variabel-variabel independen dalam menjelaskan variasi variabel dependen amat terbatas. Nilai yang mendekati satu berarti variabel-variabel independen memberikan hampir semua informasi yang dibutuhkan untuk memprediksi variasi variabel dependen.

Kelemahan mendasar dalam penggunaan koefisien determinasi adalah bisa terhadap jumlah variabel independen yang dimasukkan ke dalam model. Setiap tambahan satu variabel independen ke dalam model, maka $\mathrm{R}^{2}$ pasti meningkat tidak peduli apakah variabel independen tersebut berpengaruh secara signifikan terhadap variabel dependen. Oleh karena itu banyak peneliti menganjurkan untuk menggunakan nilai adjusted $\mathrm{R}^{2}$ pada saat mengevaluasi mana model regresi terbaik. Tidak seperti $\mathrm{R}^{2}$, nilai adjusted $\mathrm{R}^{2}$ dapat naik atau turun apabila satu variabel independen ditambahkan kedalam model (Aripin, 2016).

Koefisien determinasi mengukur seberapa jauh kemampuan model dalam menerangkan variasi variabel independen. Nilai $\mathrm{R}^{2}$ mempunyai interval mulai dari 0 sampai $1\left(0 \leq R^{2} \leq 1\right)$. Semakin besar $R^{2}$ (mendekati 1), semakin baik model regresi tersebut. Semakin mendekati 0 maka variabel independen secara keseluruhan tidak dapat menjelaskan variabilitas dari variabel independen (Aripin, 2017).

\section{Pembahasan dan Hasil}

\subsection{Karakteristik Data}

Karakteristik data pada penelitian ini dapat dilihat pada table 4.1 dibawah ini:

Tabel 4.1 Karakteristik Data

\begin{tabular}{|l|c|}
\hline \multicolumn{1}{|c|}{ Keterangan } & Jumlah \\
\hline Kuesioner yang disebarkan & 40 \\
\hline Kuesioner yang tidak kembali & 0 \\
\hline Kuesioner yang kembali & 40 \\
\hline Total sampel yang digunakan & $\mathbf{4 0}$ \\
\hline
\end{tabular}

Sumber: Data diolah sendiri

Berdasarkan tabel 4.1 dari 40 kuesioner yang dibagikan, kuesioner kembali berjumlah 40. Dari hasil penetapan sampel sebesar 40, peneliti mendapatkan kuesioner sejumlah sampel atau responden yang telah ditetapkan.

Tabel 4.2 Karakteristik Umum Responden

\begin{tabular}{|c|c|c|c|}
\hline Keterangan & & Frekuensi & $\begin{array}{l}\text { Presentase } \\
(\%)\end{array}$ \\
\hline Jenis & Laki-laki & 26 & $65,0 \%$ \\
\hline Kelamin & $\begin{array}{l}\text { Perempua } \\
\text { n }\end{array}$ & 14 & $35,0 \%$ \\
\hline Pendidikan & D3 & 8 & $20,0 \%$ \\
\hline Terakhir & $\mathrm{D} 4 / \mathrm{S} 1$ & 29 & $72,5 \%$ \\
\hline & S2 & 3 & $7,5 \%$ \\
\hline Lama & 1-5 tahun & 3 & $7,5 \%$ \\
\hline Bekerja & $>5$ tahun & 37 & $92,5 \%$ \\
\hline Jumlah Sam & pel & 40 & $100 \%$ \\
\hline
\end{tabular}

Berdasarkan tabel 4.2 diperoleh informasi bahwa responden berjenis kelamin laki-laki berjumlah 26 responden dengan presentase $65,0 \%$, responden dengan jenis kelamin laki-laki dalam penelitian ini lebih banyak dibandingkan dengan perempuan yang berjumlah 14 responden dengan persentase sebesar $35,0 \%$. Jumlah responden dengan pendidikan terakhir D4/S1 memiliki jumlah yang paling banyak berjumlah 29 responden dengan presentase sebesar $72,5 \%$. Untuk waktu lama bekerja responden, paling banyak $>5$ tahun dilihat dari besarnya persentase yaitu $92,5 \%$.

\subsection{Statistik Deskriptif}

Penyajian statistik deskriptif bertujuan untuk menggambarkan data penelitian per variabel. Berikut adalah pernyataan kuesioner yang telah diajukan 
kepada responden diperoleh berbagai macam tanggapan. Berbagai tanggapan dari responden tersebut dapat disajikan sebagai berikut :

\begin{tabular}{|c|c|c|c|c|c|c|c|c|c|}
\hline \multirow{2}{*}{\multicolumn{2}{|c|}{ Tabel 4.3}} & \multicolumn{3}{|c|}{$\begin{array}{l}\text { Distribusi } \\
\text { Responden }\end{array}$} & \multicolumn{3}{|c|}{$\begin{array}{c}\text { Frekuensi } \\
\text { Terhadap }\end{array}$} & \multicolumn{2}{|c|}{$\begin{array}{l}\text { Jawaban } \\
\text { Variabel }\end{array}$} \\
\hline & & \multicolumn{8}{|c|}{ Kinerja Non-keuangan } \\
\hline \multicolumn{10}{|c|}{ Kinerja Non-keuangan } \\
\hline \multirow{2}{*}{ Item } & \multicolumn{8}{|c|}{ Jawaban Responden Frekuensi } & \multirow{2}{*}{ Total } \\
\hline & TS & $\%$ & $\mathrm{CS}$ & $\%$ & $\mathbf{S}$ & $\%$ & SS & $\%$ & \\
\hline \multirow[t]{2}{*}{ Y.1 } & & 2,5 & & & & & & & \\
\hline & 1 & $\%$ & 9 & $22,5 \%$ & 20 & $50,0 \%$ & 10 & $25,0 \%$ & 40 \\
\hline \multirow[t]{2}{*}{ Y.2 } & & 2,5 & & & & & & & \\
\hline & 1 & $\%$ & 7 & $17,5 \%$ & 17 & $42,5 \%$ & 15 & $37,5 \%$ & 40 \\
\hline Y.3 & 0 & 0 & 9 & $22,5 \%$ & 25 & $62,5 \%$ & 6 & $15,0 \%$ & 40 \\
\hline Y.4 & 0 & 0 & 7 & $17,5 \%$ & 23 & $57,5 \%$ & 10 & $25,0 \%$ & 40 \\
\hline \multirow[t]{2}{*}{ Y.5 } & & 2,5 & & & & & & & \\
\hline & 1 & $\%$ & 10 & $25,0 \%$ & 20 & $50,0 \%$ & 9 & $22,5 \%$ & 40 \\
\hline Y.6 & 0 & 0 & 5 & $12,5 \%$ & 24 & $60,0 \%$ & 11 & $27,5 \%$ & 40 \\
\hline Y.7 & 0 & 0 & 10 & $25,0 \%$ & 24 & $60,0 \%$ & 6 & $15,0 \%$ & 40 \\
\hline Y.8 & 0 & 0 & 11 & $27,5 \%$ & 23 & $57,5 \%$ & 6 & $15,0 \%$ & 40 \\
\hline Y.9 & 0 & 0 & 6 & $15,0 \%$ & 26 & $65,0 \%$ & 8 & $20,0 \%$ & 40 \\
\hline Y.10 & 0 & 0 & 5 & $12,5 \%$ & 24 & $60,0 \%$ & 11 & $27,5 \%$ & 40 \\
\hline
\end{tabular}

Sumber : diolah sendiri

Berdasarkan tabel 4.3, variabel kinerja non-keuangan dapat diketahui bahwa secara umum para responden cenderung memilih setuju dan sangat setuju dengan pertanyaan-pertanyaan mengenai kinerja non-keuangan. Hal ini menunjukkan bahwa kinerja non-keuangan ini sangat berpengaruh besar terhadap responden.

Tabel 4.4 Distribusi Frekuensi Jawaban

Responden Terhadap Variabel

Transparancy

\begin{tabular}{|c|c|c|c|c|c|c|c|c|c|}
\hline \multicolumn{7}{|c|}{ Transparancy } \\
\cline { 1 - 9 } Item & \multicolumn{7}{|c|}{ Frekuensi Jawaban Responden } & \multirow{2}{*}{ Total } \\
\cline { 2 - 9 } & TS & $\%$ & CS & $\%$ & S & $\%$ & SS & $\%$ & \\
\hline X1.1 & 0 & 0 & 9 & $22,5 \%$ & 22 & 55,05 & 9 & $22,5 \%$ & 40 \\
\hline X1.2 & 0 & 0 & 6 & $15,0 \%$ & 26 & $65,0 \%$ & 8 & $20,0 \%$ & 40 \\
\hline X1.3 & 0 & 0 & 7 & $17,5 \%$ & 26 & $65,0 \%$ & 7 & $17,5 \%$ & 40 \\
\hline X1.4 & 2 & $5,0 \%$ & 15 & $37,5 \%$ & 23 & $57,5 \%$ & 0 & 0 & 40 \\
\hline X1.5 & 0 & 0 & 9 & $22,5 \%$ & 21 & $52,5 \%$ & 10 & $25,0 \%$ & 40 \\
\hline
\end{tabular}

Sumber : diolah sendiri

Berdasarkan tabel 4.4, variabel transparancy dapat diketahui bahwa secara umum para responden cenderung memilih setuju dan sangat setuju dengan pertanyaan-pertanyaan mengenai transparancy. Hal ini menunjukkan bahwa transparancy ini sangat berpengaruh besar terhadap responden.

Tabel 4.5 Distribusi Frekuensi Jawaban

Responde Terhadap Variabel Accountability

\begin{tabular}{|c|c|c|c|c|c|c|c|c|c|}
\hline \multicolumn{7}{|c|}{ Accountability } \\
\cline { 1 - 8 } Item & \multicolumn{7}{|c|}{ Trekuensi Jawaban Responden } \\
\cline { 2 - 9 } & TS & $\%$ & CS & $\%$ & S & $\%$ & SS & $\%$ & \\
\hline X2.1 & 2 & $5,0 \%$ & 13 & $32,5 \%$ & 24 & $60,0 \%$ & 1 & $2,5 \%$ & 40 \\
\hline X2.2 & 0 & 0 & 9 & $22,5 \%$ & 25 & $62,5 \%$ & 6 & $15,0 \%$ & 40 \\
\hline X2.3 & 0 & 0 & 7 & $17,5 \%$ & 24 & 60,0 & 9 & $22,5 \%$ & 40 \\
\hline X2.4 & 0 & 0 & 7 & $17,5 \%$ & 26 & $65,0 \%$ & 7 & $17,5 \%$ & 40 \\
\hline X2.5 & 0 & 0 & 4 & $10,0 \%$ & 30 & $75,0 \%$ & 6 & $15,0 \%$ & 40 \\
\hline
\end{tabular}

Sumber : diolah sendiri

Berdasarkan tabel 4.5, variabel accountability dapat diketahui bahwa secara umum para responden cenderung memilih setuju dan sangat setuju dengan pertanyaan-pertanyaan mengenai accountability. Hal ini menunjukkan bahwa accountability ini sangat berpengaruh besar terhadap responden.

Tabel 4.6 Distribusi Frekuensi Jawaban

Responde Terhadap Variabel

Responsibility

\begin{tabular}{|c|c|c|c|c|c|c|c|c|c|}
\hline \multicolumn{10}{|c|}{ Responsibility } \\
\hline \multirow{2}{*}{ Item } & \multicolumn{8}{|c|}{ Frekuensi Jawaban Responden } & \multirow{2}{*}{ Total } \\
\hline & TS & $\%$ & $\mathbf{C S}$ & $\%$ & $\mathbf{S}$ & $\%$ & SS & $\%$ & \\
\hline $\mathbf{X 3 . 1}$ & 2 & $5,0 \%$ & 14 & $35,0 \%$ & 24 & $60,0 \%$ & 0 & 0 & 40 \\
\hline $\mathbf{X 3 . 2}$ & 0 & 0 & 6 & $15,0 \%$ & 26 & $65,0 \%$ & 8 & $20,0 \%$ & 40 \\
\hline $\mathbf{X 3 . 3}$ & 0 & 0 & 7 & $17,5 \%$ & 21 & $52,5 \%$ & 12 & $30,0 \%$ & 40 \\
\hline $\mathbf{X 3 . 4}$ & 1 & $2,5 \%$ & 6 & $15,0 \%$ & 24 & $60,0 \%$ & 9 & $22,5 \%$ & 40 \\
\hline
\end{tabular}

Sumber : diolah sendiri

Berdasarkan tabel 4.6, variabel responsibility dapat diketahui bahwa secara umum para responden cenderung memilih setuju dan sangat setuju dengan pertanyaan-pertanyaan mengenai responsibility. Hal ini menunjukkan bahwa responsibility ini sangat berpengaruh besar terhadap responden. 
Tabel 4.7 Distribusi Frekuensi Jawaban

\begin{tabular}{|c|c|c|c|c|c|c|c|c|c|}
\hline \multicolumn{10}{|c|}{$\begin{array}{l}\text { Responden } \\
\text { Independency }\end{array}$} \\
\hline \multicolumn{10}{|c|}{ Independency } \\
\hline \multirow{2}{*}{ Item } & \multicolumn{8}{|c|}{ Frekuensi Jawaban Responden } & \multirow{2}{*}{ Total } \\
\hline & $\mathbf{T S}$ & $\%$ & $\mathrm{CS}$ & $\%$ & $\mathbf{S}$ & $\%$ & SS & $\%$ & \\
\hline $\mathrm{X} 4.1$ & 1 & $2,5 \%$ & 9 & $22,5 \%$ & 19 & $47,5 \%$ & 11 & $27,5 \%$ & 40 \\
\hline $\mathrm{X} 4.2$ & 1 & $2,5 \%$ & 7 & $17,5 \%$ & 17 & $42,5 \%$ & 15 & $37,5 \%$ & 40 \\
\hline $\mathrm{X} 4.3$ & 0 & 0 & 9 & $22,5 \%$ & 25 & $62,5 \%$ & 6 & $15,0 \%$ & 40 \\
\hline $\mathrm{X} 4.4$ & 2 & $5,0 \%$ & 10 & $25,5 \%$ & 23 & $12,5 \%$ & 5 & $12,5 \%$ & 40 \\
\hline $\mathbf{X} 4.5$ & 1 & $2,5 \%$ & 10 & $25,0 \%$ & 20 & $50,0 \%$ & 9 & $22,5 \%$ & 40 \\
\hline
\end{tabular}

Sumber : diolah sendiri

Berdasarkan tabel 4.7, variabel independency dapat diketahui bahwa secara umum para responden cenderung memilih setuju dan sangat setuju dengan pertanyaan-pertanyaan mengenai independency. Hal ini menunjukkan bahwa independency ini sangat berpengaruh besar terhadap responden.

Tabel 4.8 Distribusi Frekuensi Jawaban

Responde Terhadap Variabel

Fairness

\begin{tabular}{|c|c|c|c|c|c|c|c|c|c|}
\hline \multicolumn{7}{|c|}{ Fairness } \\
\hline \multirow{2}{*}{ Item } & \multicolumn{7}{|c|}{ Frekuensi Jawaban Responden } & \multirow{2}{*}{ Total } \\
\cline { 2 - 9 } & TS & $\%$ & CS & $\%$ & S & $\%$ & SS & $\%$ & \\
\hline X5.1 & 1 & $2,5 \%$ & 9 & $22,5 \%$ & 19 & $47,5 \%$ & 11 & $27,5 \%$ & 40 \\
\hline X5.2 & 1 & $2,5 \%$ & 7 & $17,5 \%$ & 17 & $42,5 \%$ & 15 & $37,5 \%$ & 40 \\
\hline X5.3 & 0 & 0 & 9 & $22,5 \%$ & 25 & $62,5 \%$ & 6 & $15,0 \%$ & 40 \\
\hline X5.4 & 2 & $5,0 \%$ & 10 & $25,5 \%$ & 23 & $12,5 \%$ & 5 & $12,5 \%$ & 40 \\
\hline X5.5 & 1 & $2,5 \%$ & 10 & $25,0 \%$ & 20 & $50,0 \%$ & 9 & $22,5 \%$ & 40 \\
\hline
\end{tabular}

Sumber : diolah sendiri

Berdasarkan tabel 4.8, variabel fairness dapat diketahui bahwa secara umum para responden cenderung memilih setuju dan sangat setuju dengan pertanyaan-pertanyaan mengenai fairness. Hal ini menunjukkan bahwa fairness ini sangat berpengaruh besar terhadap responden.

\subsection{Pengujian Instrumen \\ 4.3.1 Uji Validitas}

Ghozali (2012) menyatakan bahwa uji validitas digunakan untuk mengukur sah atau valid tidaknya suatu kuesioner. Suatu instrumen yang sah atau valid memiliki nilai validitas yang tinggi dan sebaliknya untuk instrumen yang kurang valid berarti memiliki validitas yang rendah. Teknik pengujian yang sering digunakan para peneliti untuk uji validitas adalah menggunakan korelasi Bivariate Pearson. Menganalisis dengan cara mengkorelasikan masing-masing skor item dengan skor total. Skor total adalah penjumlahan dari keseluruhan item-item pertanyaan yang berkorelasi signifikan dengan skor total menunjukkan item-item tersebut mampu memberikan dukungan dalam mengungkap apa yang ingin diungkap adalah valid. Dengan jumlah sampel (n) adalah 40 tingkat signifikansi 0,05 maka $\mathrm{r}$ tabel pada penelitian ini adalah : $\mathrm{R}(0,05: 40-3=37) 0,3160$

Tabel 4.9 Hasil Uji Validitas Variabel Kinerja Non-keuangan

\begin{tabular}{|c|c|c|c|}
\hline $\begin{array}{c}\text { Variabel } \\
\text { Kinerja }\end{array}$ & $\mathbf{r}$ hitung & $\mathbf{r}$ tabel & Kesimpulan \\
\hline Q1 & 0,602 & & Valid \\
\hline Q2 & 0,497 & & Valid \\
\hline Q3 & 0,566 & & Valid \\
\hline Q4 & 0,343 & & Valid \\
\hline Q5 & 0,750 & $\mathbf{0 , 3 1 6 0}$ & Valid \\
\hline Q6 & 0,561 & & Valid \\
\hline Q7 & 0,494 & & Valid \\
\hline Q8 & 0,600 & & Valid \\
\hline Q9 & 0,367 & & Valid \\
\hline Q10 & 0,561 & & Valid \\
\hline
\end{tabular}

Sumber : Data SPPS yang diolah 2018

Dari Tabel 4.9 Hasil pengujian Validitas $Y$ Kinerja Non-keuangan diperoleh bahwa semua indikator yang digunakan untuk mengukur variabel-variabel yang digunakan dalam penelitian ini mempunyai koefisien korelasi yang lebih besar dari $r_{\text {tabel }}=0,3160$ (nilai $r_{\text {tabel }}$ untuk $n=37$ ), sehingga semua indikator tersebut adalah valid.

Tabel 4.10 Hasil Uji Validitas Variabel Transparancy

\begin{tabular}{|c|c|c|c|}
\hline $\begin{array}{c}\text { Variabel } \\
\text { Transparancy }\end{array}$ & r hitung & r tabel & Kesimpulan \\
\hline Q1 & 0,740 & & Valid \\
\hline Q2 & 0,721 & & Valid \\
\hline Q3 & 0,761 & $\mathbf{0 , 3 1 6 0}$ & Valid \\
\hline Q4 & 0,496 & & Valid \\
\hline Q5 & 0,727 & & Valid \\
\hline
\end{tabular}

Sumber : Data SPSS yang diolah 2018

Dari Tabel 4.10 Hasil pengujian Validitas X1 
Transparancy diperoleh bahwa semua indikator yang digunakan untuk mengukur variabel-variabel yang digunakan dalam penelitian ini mempunyai koefisien korelasi yang lebih besar dari $r_{\text {tabel }}=0,3160$ (nilai $r_{\text {tabel }}$ untuk $n=37$ ), sehingga semua indikator tersebut adalah valid.

hdzh

Tabel 4.11 Hasil Uji Validitas Variabel Accountability

\begin{tabular}{|c|c|c|c|}
\hline $\begin{array}{c}\text { Variabel } \\
\text { Accountability }\end{array}$ & $\mathbf{r}$ hitung & r tabel & Kesimpulan \\
\hline Q1 & 0,478 & & Valid \\
\hline Q2 & 0,842 & & Valid \\
\hline Q3 & 0,526 & $\mathbf{0 , 3 1 6 0}$ & Valid \\
\hline Q4 & 0,868 & & Valid \\
\hline Q5 & 0,882 & & Valid \\
\hline
\end{tabular}

Sumber : Data SPSS yang diolah 2018

Dari Tabel 4.11 Hasil pengujian Validitas X2 Accountability diperoleh bahwa semua indikator yang digunakan untuk mengukur variabel-variabel yang digunakan dalam penelitian ini mempunyai koefisien korelasi yang lebih besar dari $r_{\text {tabel }}=0,3160$ (nilai $r_{\text {tabel }}$ untuk $\mathrm{n}=37$ ), sehingga semua indikator tersebut adalah valid.

Tabel 4.12 Hasil Uji Validitas Variabel Responsibility

\begin{tabular}{|c|c|c|c|}
\hline $\begin{array}{c}\text { Variabel } \\
\text { Responsibility }\end{array}$ & r hitung & r tabel & Kesimpulan \\
\hline Q1 & 0,589 & & Valid \\
\hline Q2 & 0,834 & & Valid \\
\hline Q3 & 0,682 & $\mathbf{0 , 3 1 6 0}$ & Valid \\
\hline Q4 & 0,880 & & Valid \\
\hline
\end{tabular}

Sumber : Data SPSS yang diolah 2018

Dari Tabel 4.12 Hasil pengujian Validitas X3 Responsibility diperoleh bahwa semua indikator yang digunakan untuk mengukur variabel-variabel yang digunakan dalam penelitian ini mempunyai koefisien korelasi yang lebih besar dari $r_{\text {tabel }}=0,3160$ (nilai $r_{\text {tabel }}$ untuk $n=37$ ), sehingga semua indikator tersebut adalah valid.
Tabel 4.13 Hasil Uji Validitas Variabel Independency

\begin{tabular}{|c|c|c|c|}
\hline $\begin{array}{c}\text { Variabel } \\
\text { Transparancy }\end{array}$ & $\begin{array}{c}\mathbf{r} \\
\text { hitung }\end{array}$ & r tabel & Kesimpulan \\
\hline Q1 & 0,738 & & Valid \\
\hline Q2 & 0,577 & & Valid \\
\hline Q3 & 0,627 & $\mathbf{0 , 3 1 6 0}$ & Valid \\
\hline Q4 & 0,417 & & Valid \\
\hline Q5 & 0,805 & & Valid \\
\hline
\end{tabular}

Sumber : Data SPSS yang diolah 2018

Dari Tabel 4.13 Hasil pengujian Validitas X4 Independency diperoleh bahwa semua indikator yang digunakan untuk mengukur variabel-variabel yang digunakan dalam penelitian ini mempunyai koefisien korelasi yang lebih besar dari $r_{\text {tabel }}=0,3160$ (nilai $r_{\text {tabel }}$ untuk $n=37$ ), sehingga semua indikator tersebut adalah valid.

Tabel 4.14 Hasil Uji Validitas Variabel Fairness

\begin{tabular}{|c|c|c|c|}
\hline $\begin{array}{c}\text { Variabel } \\
\text { Fairness }\end{array}$ & r hitung & r tabel & Kesimpulan \\
\hline Q1 & 0,675 & & Valid \\
\hline Q2 & 0,598 & & Valid \\
\hline Q3 & 0,669 & $\mathbf{0 , 3 1 6 0}$ & Valid \\
\hline Q4 & 0,761 & & Valid \\
\hline Q5 & 0,707 & & Valid \\
\hline
\end{tabular}

Sumber : Data SPSS yang diolah 2018

Dari Tabel 4.14 Hasil pengujian Validitas X5 Fairness diperoleh bahwa semua indikator yang digunakan untuk mengukur variabel-variabel yang digunakan dalam penelitian ini mempunyai koefisien korelasi yang lebih besar dari $r_{\text {tabel }}=0,3160$ (nilai $r_{\text {tabel }}$ untuk $n=37$ ), sehingga semua indikator tersebut adalah valid.

\subsubsection{Uji Reliabilitas}

Pengukuran reliabilitas dilakukan dengan uji statistik Cronbach Alpha. Suatu variabel dikatakan reliabel apabila memberikan nilai Cronbach Alpha > 0,60 (Ghozali, 2011). 
Tabel 4.15 Uji Reliabilitas

\begin{tabular}{|l|c|c|}
\hline Keterangan & $\begin{array}{c}\text { Cronbach's } \\
\text { Alpha }\end{array}$ & Kesimpulan \\
\hline Transparancy & 0,725 & Reliabel \\
\hline Accountability & 0,750 & Reliabel \\
\hline Responsibility & 0,736 & Reliabel \\
\hline Independency & 0,624 & Reliabel \\
\hline Fairness & 0,702 & Reliabel \\
\hline $\begin{array}{l}\text { Kinerja } \\
\text { Non-keuangan }\end{array}$ & 0,721 & Reliabel \\
\hline
\end{tabular}

Sumber : Data SPSS yang diolah 2018

Berdasarkan hasil uji realibilitas pada tabel 4.15 maka dapat disimpulkan bahwa kuesioner yang digunakan dalam peneliti sudah dikatakan reliabel karena nilai Cronbach's Alpha dari masing-masing variabel lebih besar dari 0,60 .

\subsection{Uji Asumsi Klasik}

\subsubsection{Uji Normalitas}

\section{Gambar 4.1 Hasil Uji Normalitas}

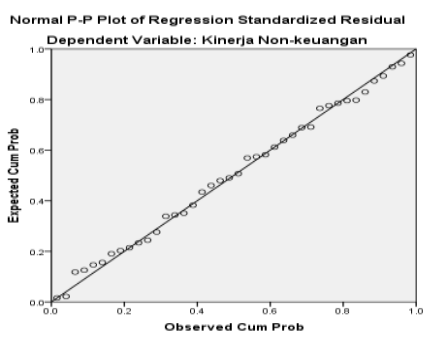

Sumber : Data SPSS yang diolah 2018

Uji normalitas adalah uji untuk mengukur apakah data yang kita miliki berdistribusi normal sehingga dapat dipakai dalam statistik parametrik. Untuk mengetahui apakah data dalam penelitian ini berdistribusi normal atau tidak maka dilakukan pengujian dengan Probability Plot. Dari gambar Probability Plot diatas diperoleh bahwa data menyebar disekitar garis diagonal, maka model regresi memenuhi asumsi normalitas.

\subsection{Pengujian Hipotesis}

Uji statistik $\mathrm{t}$ digunakan untuk mengetahui seberapa jauh masing-masing variabel transparancy, accountability, responsibility, independency, dan fairness dalam menerangkan variabel kinerja non-keuangan. Dalam hal ini, apakah masing-masing variabel transparancy, accountability, responsibility, independency, dan fairness mempengaruhi variabel kinerja non-keuangan. Berikut hasil pengujian parameter individual (Uji Statistik t):

Tabel 4.16 Hasil Uji Hipotesis

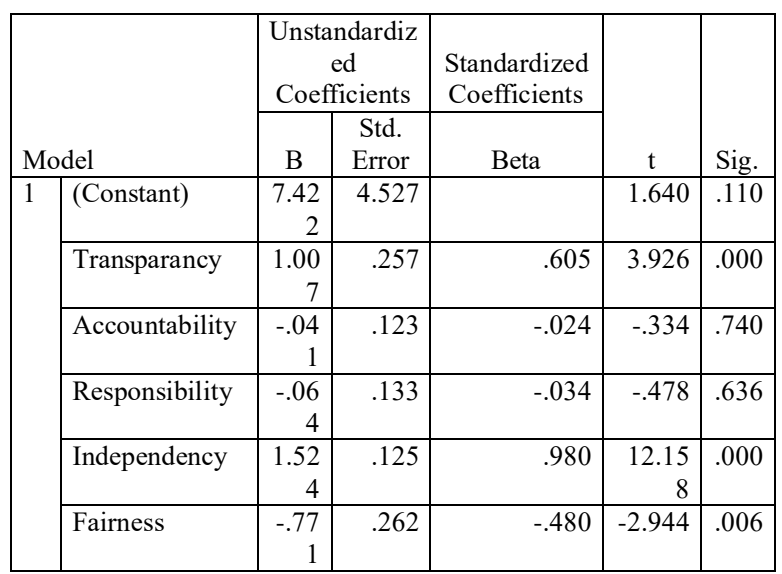

Sumber : Data SPSS yang diolah 2018

Hipotesis pada penelitian ini adalah transparancy berpengaruh signifikan terhadap kinerja non-keuangan. Berdasarkan hasil uji t pada Tabel 4.16 diatas dapat diketahui bahwa koefisien b transparancy bernilai positif sebesar 1,007, maka kedua variabel tersebut memiliki hubungan yang searah, dalam arti lain peningkatan variabel X1 transparancy akan diikuti dengan peningkatan variabel $\mathrm{Y}$ kinerja non-keuangan, dan nilai signifikansi $0,000<0,05$. Hal ini berarti bahwa transparancy berpengaruh signifikan terhadap kinerja non-keuangan.

Hipotesis pada penelitian ini adalah accountability berpengaruh signifikan terhadap kinerja non-keuangan. Berdasarkan hasil uji t pada Tabel 4.16 diatas dapat diketahui bahwa koefisien $b$ accountability bernilai negatif sebesar -0,041, dalam arti lain peningkatan X2 accountability akan diikuti dengan peningkatan variabel Y kinerja non-keuangan, dan nilai signifikansi $0.740>0,05$. Hal ini berarti bahwa accountability berpengaruh tidak signifikan terhadap kinerja non-keuangan.

Hipotesis pada penelitian ini adalah responsibility berpengaruh signifikan terhadap kinerja non-keuangan. Berdasarkan hasil uji t pada Tabel 4.16 diatas dapat diketahui bahwa koefisien $\mathrm{b}$ responsibility 
bernilai negatif sebesar -0,064, dalam arti lain peningkatan variabel $\mathrm{X} 3$ responsibility akan diikuti dengan peningkatan variabel $\mathrm{Y}$ kinerja non-keuangan, dan nilai signifikansi $0.636>0,05$. Hal ini berarti bahwa responsibility berpengaruh tidak signifikan terhadap kinerja non-keuangan.

Hipotesis pada penelitian ini adalah independency berpengaruh signifikan terhadap kinerja non-keuangan. Berdasarkan hasil uji t pada Tabel 4.16 diatas dapat diketahui bahwa koefisien b independency bernilai positif sebesar 1,524, dalam arti lain peningkatan variabel X3 independency akan diikuti dengan peningkatan variabel Y kinerja non-keuangan, dan nilai signifikansi $0.000<0,05$. Hal ini berarti bahwa independency berpengaruh signifikan terhadap kinerja non-keuangan.

Hipotesis pada penelitian ini adalah fairness berpengaruh signifikan terhadap kinerja non-keuangan. Berdasarkan hasil uji t pada Tabel 4.16 diatas dapat diketahui bahwa koefisien $b$ fairness bernilai negatif sebesar -0,771, dalam arti lain peningkatan variabel X3 fairness akan diikuti dengan peningkatan variabel $\mathrm{Y}$ kinerja non-keuangan, dan nilai signifikansi 0,006 $<0,05$. Hal ini berarti bahwa responsibility berpengaruh signifikan terhadap kinerja non-keuangan.

\section{Kesimpulan}

Penelitian ini bertujuan untuk meneliti mengenai pengaruh penerapan prinsip GCG terhadap kinerja non keuangan b'right PLN Batam yang memenuhi syarat untuk dijadikan sampel dalam penelitian ini. Berdasarkan hasil analisis dapat ditarik kesimpulan sebagai berikut:

Diketahui bahwa koefisien b transparancy bernilai positif sebesar 1,007 maka kedua variabel tersebut memiliki hubungan yang searah, dalam arti lain peningkatan variabel X1 transparancy akan diikuti dengan peningkatan variabel $\mathrm{Y}$ kinerja non-keuangan. Dengan tingkat signifikan 0,000 $<0,05$. Yang dapat disimpulkan bahwa transparancy berpengaruh positif dan signifikan terhadap kinerja non-keuangan.

Diketahui bahwa koefisien b accountability bernilai negatif sebesar -0,041 maka kedua variabel tersebut memiliki hubungan yang tidak searah, dalam arti lain peningkatan variabel X2 accountability tidak diikuti dengan peningkatan variabel $\mathrm{Y}$ kinerja non-keuangan. Dengan tingkat signifikan 0,740>0,05. Yang dapat disimpulkan bahwa accountability berpengaruh negatif dan tidak signifikan terhadap kinerja non-keuangan.

Diketahui bahwa koefisien $\mathrm{b}$ responsibility bernilai negatif sebesar -0,064 maka kedua variabel tersebut memiliki hubungan yang tidak searah, dalam arti lain peningkatan variabel $\mathrm{X} 3$ responsibility tidak diikuti dengan peningkatan variabel $\mathrm{Y}$ kinerja non-keuangan. Dengan tingkat signifikan 0,636>0,05. Yang dapat disimpulkan bahwa responsibility berpengaruh negatif dan tidak signifikan terhadap kinerja non-keuangan.

Diketahui bahwa koefisien $\mathrm{b}$ independency bernilai positif sebesar 1,524 maka kedua variabel tersebut memiliki hubungan yang searah, dalam arti lain peningkatan variabel $\mathrm{X} 4$ independency akan diikuti dengan peningkatan variabel $\mathrm{Y}$ kinerja non-keuangan. Dengan tingkat signifikan 0,000 < 0,05. Yang dapat disimpulkan bahwa independency berpengaruh positif dan signifikan terhadap kinerja non-keuangan.

Diketahui bahwa koefisien b fairness bernilai negatif sebesar $-0,771$ maka kedua variabel tersebut memiliki hubungan yang tidak searah, dalam arti lain peningkatan variabel X5 fairness tidak diikuti dengan peningkatan variabel Y kinerja non-keuangan. Dengan tingkat signifikan $0,006<0,05$. Yang dapat disimpulkan bahwa responsibility berpengaruh negatif dan signifikan terhadap kinerja non-keuangan.

\section{Keterbatasan}

Dengan keterbatasan waktu, sarana dan prasarana serta tidak menyimpangnya tujuan penelitian yang dilakukan, maka penulis membagi penelitian pada 5 (lima) variabel independen yaitu: transparency, 
accountability, responsibility, independency dan fairness, peneliti hanya mendapatkan data secara garis besar yang didapat melalui penyebaran kuisioner dan observasi langsung di perusahaan b'right PLN Batam dalam kurun waktu selama 3 (tiga) bulan.

\section{Saran}

Berdasarkan hasil penelitian dan kesimpulan yang didaptakan dalam penelitian ini, maka saran yang dapat penulis berikan sebagai berikut: (1) untuk penelitian selanjutnya, sebaiknya mengambil sampel dengan seluruh jajaran struktular; (2) penelitian selanjutnya dapat menambahkan variabel independen lain yang berkemungkinan besar dapat mempengaruhi kinerja.

\section{Daftar Pustaka}

Aggarwal, P. (2013). Corporate Governance and Corporate Profitability: Are they Related? - A Study in Indian Context. Internasional Journal of Scientific an D Research Publication, 3(12), 1-8.

Aripin, Akbar. (2016). Determinasi Gaya Kepemimpinan, Motivasi dan Kompetensi terhadap Kinerja Karyawan PT. Ghim Li Indonesia. Batam: Fakultas Ekonom Universitas Batam.

Brigham, E. (2011). Dasar - Dasar Manajemen Keuangan (11th ed.). Jakarta: Salemba empat.

Dewi, Kadek Krismaya dan Dwijaputri, IGA M. Asri Dwijaputri. (2014). PENGARUH PENERAPAN PRINSIP-PRINSIP GCG PADA KINERJA KEUANGAN LEMBAGA PERKREDITAN DESA KABUPATEN GIANYAR BALI. E-Jurnal Akuntansi Universitas Udayana 7.3 (2014): 559-573.

Irwondy, Irvian Syahbani (2016). Pengaruh Penerapan Good Corporate Governnace Terhadap
Kinerja Non-Keuangan di Kantor Pusat PT Asuransi Jasa Indonesia. Jurnal Manajmen dan Organisasi Vol VII No 2 Agustus 2016: 99-110.

Kaihatu, T. S. (2006). Good Corporate Governance dan Penerapannya di Indonesia. Jurnal Manajemen Dan Kewirausahaan,8, 1-9.

Kementerian Badan Usaha Milik Negara. Jaringan Dokumentasi Dan Informasi Hukum Kementerian BUMN. Oktober 17, 2017.

http://jdih.bumn.go.id/ (accessed Agustus 25, 2018).

KNKG. (2018). prinsip dasar corporate governance. Retrieved February 22, 2018, from http://www.knkg-indonesia.org/

Kusumaningtyas, T. (2015). Pengaruh Good Corporate Governance Terhadap Nilai Perusahaan Yang Terdaftar Pada Indeks Sri-Kehati. Jurnal Ilmu Dan Riset Akuntansi, 4(7).

Sandraningsih, Ni Kadek Budi dan Putri, I G.A.M. Asri Dwija. (2015). PENGARUH PRINSIP-PRINSIP GOOD CORPORATE GOVERNANCE PADA KINERJA KEUANGAN LEMBAGA PERKREDITAN DESA KECAMATAN ABIANSEMAL. E-Jurnal Akuntansi Universitas Udayana 11.3 (2015): 878-893.

Lestari, P. P. (2013). Pengaruh good corporate governance terhadap kinerja perusahaan. Universitas Diponegoro.

Muryati, N. N., \& Suardikha, I. M. S. (2014). Pengaruh corporate governance pada nilai perusahaan.E-Jurnal Akuntansi Universitas Udayana, 2, 411-429. 
Nofitasari, N., Kertahadi, \& Yaningwati, F. (2015). Pengaruh Good Corporate Governance Dan Kinerja Perusahaan Terhadap Nilai Perusahaan ( Studi Pada Badan Usaha Milik Negara Yang Terdaftar Di Bursa Efek Indonesia Tahun 2010-2013 ). Jurnal Administrasi Bisnis, 25(1).

Nuswandari, C. (2009). Pengaruh corporate governance perception index terhadap kinerja perusahaan pada perusahaan yang terdaftar di bursa efek jakarta.Jurnal Bisnis Dan Ekonomi, 16(2), 70-84.

Mahaendrayasa, Putu Krishna Aryastha dan Putri, I Gusti Ayu Made Asri Dwija. (2017). PENGARUH PRINSIP-PRINSIP GOOD CORPORATE GOVERNANCE TERHADAP KINERJA KEUANGAN LEMBAGA PERKREDITAN DESA (LPD) DI KOTA DENPASAR. E-Jurnal Akuntansi Universitas Udayana Vol.21.2. November (2017): 970-995.

Mamanggi, Arilla Ratya, Suharso, Pudjo dan Sukidin. (2014). PENGARUH PELAKSANAAN PRINSIP-PRINSIP GOOD CORPORATE GOVERNANCE TERHADAP KINERJA KARYAWAN PT.PLN JEMBER. ARTIKEL ILMIAH MAHASISWA, 2014.

O’Donovan, G. (2002). Environmental disclosures in the annual report: Extending the applicability and predictive power of legitimacy theory. Accounting, Auditing \& Accountability Journal, 15.

Peter, A., \& David, A. (2014). Corporate Governance and Organizational Performance in the Nigerian Banking Industry. Journal of
Emerging Trends in Economics and Management Sciences, 5(6), 525-531.

Rofina, M., \& Priyadi, M. P. (2013). Pengaruh Penerapan Good Corporate Governance Terhadap Kinerja Keuangan Perusahaan Di BEI. Jurnal Ilmu \& Riset Akuntansi Vol., 2(1).

Rahmatika,Nurmaria, Kirmizi dan Agust, Restu. (2015). PENGARUH PENERAPAN PRINSIP-PRINSIP GOOD CORPORATE GOVERNANCE TERHADAP KINERJA KEUANGAN PERUSAHAAN (Studi pada PT Angkasa Pura II). Jurnal Akuntansi, Vol. 3, No. 2, April 2015 : 148 - 159.

Sugiyono. (2013). metode penelitian manajemen. Bandung: Alfabeta.

Sudaryo, Yoyo dan Andari, Ressy. (2017). PENGARUH PENERAPAN GOOD CORPORATE GOVERNANCE TERHADAP KINERJA PERUSAHAAN DENGAN PENDEKATAN BALANCE $\begin{array}{lll}\text { SCORECARD } & \text { PADA }\end{array}$ TELEKOMUNIKASI INDONESIA TBK . JURNAL INDONESIA MEMBANGUN. http://jurnal-inaba.hol.es/.

Santoso, Agus. (2017). PENGARUH GOOD CORPORATE GOVERNANCE TERHADAP NILAI PERUSAHAAN DENGAN KINERJA KEUANGAN SEBAGAI VARIABEL INTERVENING. Prosiding Seminar Nasional dan Call For Paper Ekonomi dan Bisnis (SNAPER-EBIS 2017) - Jember, 27-28 Oktober 2017 (hal 67-77).

Setyawan, Komang Meitradi dan Putri, I Gusti Ayu Made Asri Dwija. (2013). PENGARUH 
GOOD CORPORATE GOVERNANCE TERHADAP KINERJA KEUANGAN LEMBAGA PEKREDITAN DESA DI KECAMATAN MENGWI KABUPATEN

BADUNG. E-Jurnal Akuntansi Universitas Udayana 5.3 (2013):586-598.

Trinanda dan Mukodim. (2010). JURNAL ILMIAH MAHASISWA AKUNTANSI FAKULTAS BISNIS UNIKA WIDYA MANDALA. JURUSAN AKUNTANSI FAKULTAS BISNIS UNIKA WIDYA MANDALA SURABAYA. VOL 1, NO. 4, JULI 2012.

Ukhriyawati, C. F., Ratnawati, T., \& Riyadi, S. (2017). The Influence of Asset Structure , Capital Structure, Risk Management and Good Corporate Governance on Financial Performance and Value of The Firm through Earnings and Free Cash Flow As An Intervening Variable in Banking Companies Listed in Indonesia Sto. International Journal of Business and Manajement, 12(8), 249-260. https://doi.org/10.5539/ijbm.v12n8p249

Velnampy. (2013). Corporate Governance and Firm Performance: A Study of Sri Lankan Manufacturing Companies. Journal of Economics and Sustainable Development, 4(3).

Wibowo, agung edy. (2012). Aplikasi Praktis SPSS Dalam Penelitian. yogjakarta: Gava Media.

Wati, Like Monisa. (2012). PENGARUH PRAKTEK GOOD CORPORATE GOVERNANCE TERHADAP KINERJA KEUANGAN PERUSAHAAN DI BURSA EFEK INDONESIA. Jurnal Manajemen, Volume 01, Nomor 01, September 2012.
Yuspitasari, Sherly, Hamdani, Ikhwan dan Hakiem, H. Hilman. (2018). PENGARUH PENERAPAN PRINSIP-PRINSIP GOOD CORPORATE GOVERNANCE TERHADAP KINERJA PEGAWAI (Studi kasus Bank Syriah Mandiri Cabang Bogor). MALIA: Jurnal Ekonomi Islam Program Studi Ekonomi Syariah Universitas Yudharta Pasuruan Volume 9, Nomor 2, Juni 2018.

Zulkarnaen, N. (2015). Pengaruh Good Corporate Governance Terhadap Manajemen Pajak. Jurnal Bisnis Dan Manajemen, 5(1). quality services. New York: The Free Press a Division of Macmillan inc 866 third avenue 